\section{Reminiscência de uma fotógrafa de esportes nos anos 1990}

\section{Kátia Lombardi}

Em meados dos anos 1990, as redações dos principais jornais impressos do país estavam repletas de jovens jornalistas. Nas editorias de fotografia, embora houvesse mulheres, a predominância era masculina. Aos domingos, no quarto andar da redação da Folha de S. Paulo, havia disputa entre os fotógrafos

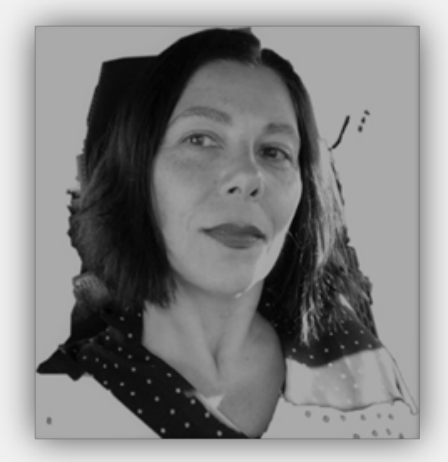
para fazer a cobertura das mais importantes partidas de futebol do dia. Nessas ocasiões, raramente a pauta era destinada a uma fotógrafa.

Se observamos hoje movimentos que reivindicam o espaço da mulher na cobertura de esportes, veremos que há 20 anos o futebol era uma área dominada pela presença masculina.

Naquela época, eu trabalhava como repórter fotográfica do jornal Notícias Populares, que fazia parte do Grupo Folha (A redação do $N P$ ficava no terceiro andar, mas compartilhávamos o laboratório de fotografia, que ficava no andar de cima, com a Folha de S. Paulo e com a Folha da Tarde).

O NP era um jornal extremamente popular, nem sempre visto com bons olhos, mas era também um veículo inovador, aberto a experimentações e que dava muito espaço para a fotografia. Um prato cheio para quem estava iniciando a profissão. Eu era a única mulher na editoria de fotografia, mas isso não me dava privilégios e nem me prejudicava. Como no NP o número de fotógrafos era reduzido, as pautas eram distribuídas para quem estivesse na redação, independentemente de quem fosse.

Assim, quando tento entender a minha inserção enquanto fotógrafa e mulher no fotojornalismo nos anos 1990, percebo que as coisas fluíram de maneira rápida. Além da rotina intensa que dificultava maiores reflexões, questionamentos sobre gênero, naquele momento, eram muito menos frequentes do que são hoje.

Foi por acaso que comecei a fotografar esportes, principalmente futebol. Os treinos geralmente aconteciam pela manhã e ainda me lembro das palavras do editor: 
"Traga uma foto do jogador tal, de perto, posada", "não me venha só com fotos de lances de treino". Queriam sempre algo diferente, para o NP não importava tanto o factual, pois podiam utilizar o material produzido pela Folha, isso nos tirava a pressão de levar furo dos concorrentes e ficávamos livres para criar cenas, experimentar enquadramentos não convencionais, usar a imaginação.

Os dias de jogos eram mais difíceis. Ao perceberem a presença de uma mulher no campo, os torcedores gritavam, assediavam, xingavam. Certa vez, ao fotografar uma torcida do alto da arquibancada, tive que ser escoltada por policiais para conseguir sair de lá ilesa.

Fotografei também outros esportes - vôlei, judô, Fórmula 1 , basquete e boxe - mas, os leitores do Notícias Populares se interessavam mesmo era pelo futebol. Corinthians e

Palmeiras eram os times que mais cobríamos.

Adquiri experiência, aprendi a antecipar lances durante a partida e a virar a câmera para o lado da torcida quando algum jogador comemorava gol. Nas mãos, tinha a câmera com uma teleobjetiva amparada por um monopé. Às vezes, pendurada no pescoço, levava uma câmera extra com lente grande angular. Nos ombros, carregava sempre a bolsa de equipamentos.

Quando fui trabalhar no jornal $O$ Tempo, em Belo Horizonte, já tinha prática em fotografar futebol e, por esse motivo, me deixaram continuar cobrindo treinos e partidas. Em 1997, o repórter Paulo Galvão e eu fomos escalados para acompanhar o time do Cruzeiro na Copa Toyota no Japão. Durante duas semanas, cobrimos os treinos, os momentos de lazer dos jogadores, as torcidas e a final. Enquanto os fotógrafos japoneses já utilizavam câmera digital, a minha câmera ainda era analógica e eu tinha que produzir, revelar e transmitir fotos para o Brasil, trabalhando com uma diferença de fuso horário de 12 horas. No dia da partida final, em Tóquio, a linha do fundo do campo estava repleta de fotógrafos. Eu me posicionei no canto esquerdo, procurei ao redor, mas não encontrei nenhuma outra mulher.

Kátia Hallak Lombardi é fotógrafa, professora do curso de Comunicação Social/Jornalismo e membro docente do Programa de Pós-graduação em Letras da Universidade Federal de São João del-Rei (UFSJ). Doutora pelo Programa de Pós-Graduação em Comunicação Social da Universidade Federal de Minas Gerais (UFMG). Pesquisadora na área de imagem, fotografia e memória.

E-mail: katialombardi@ufsj.edu.br. 


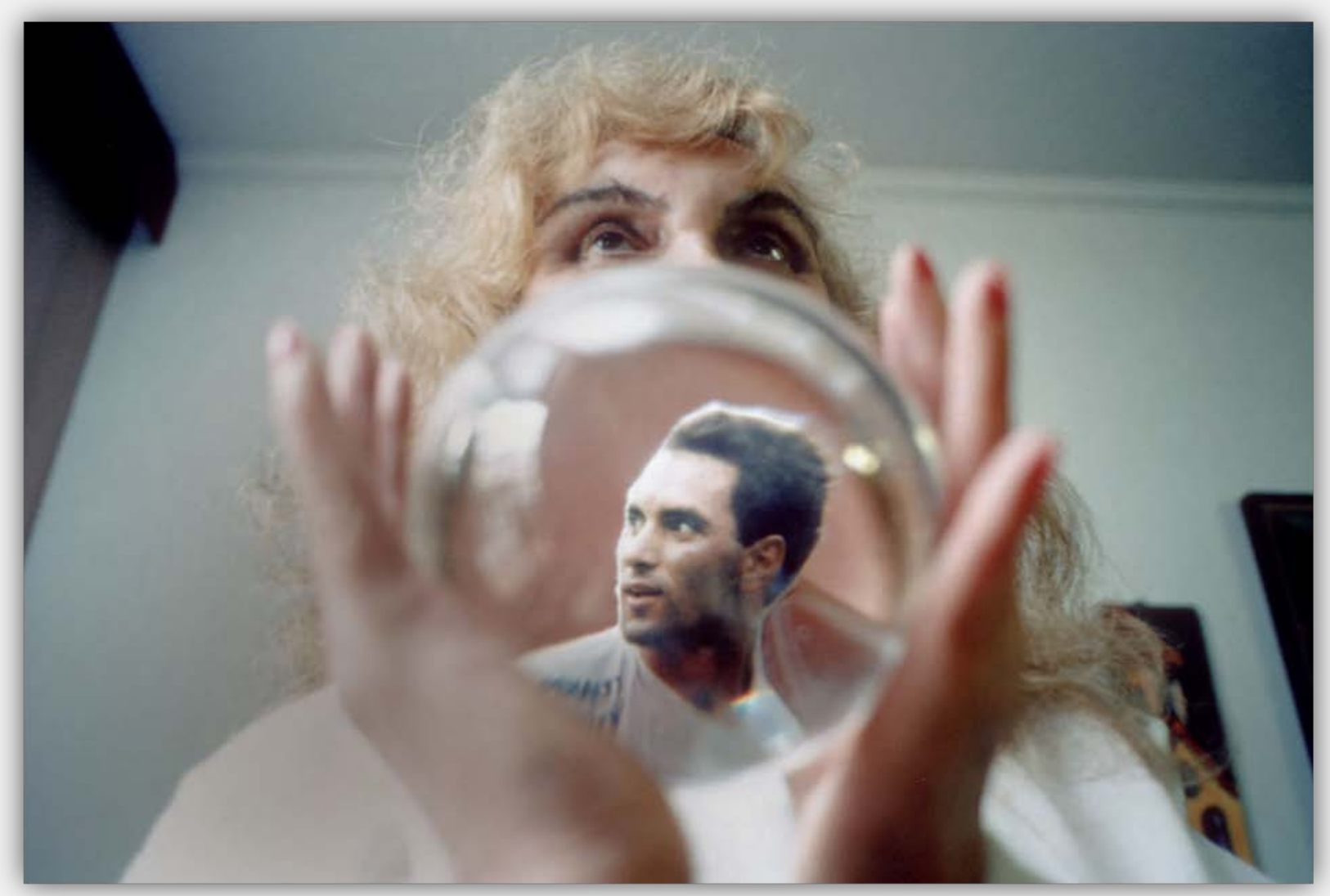

Cartomante faz previsão do desempenho de Edmundo, 1996 


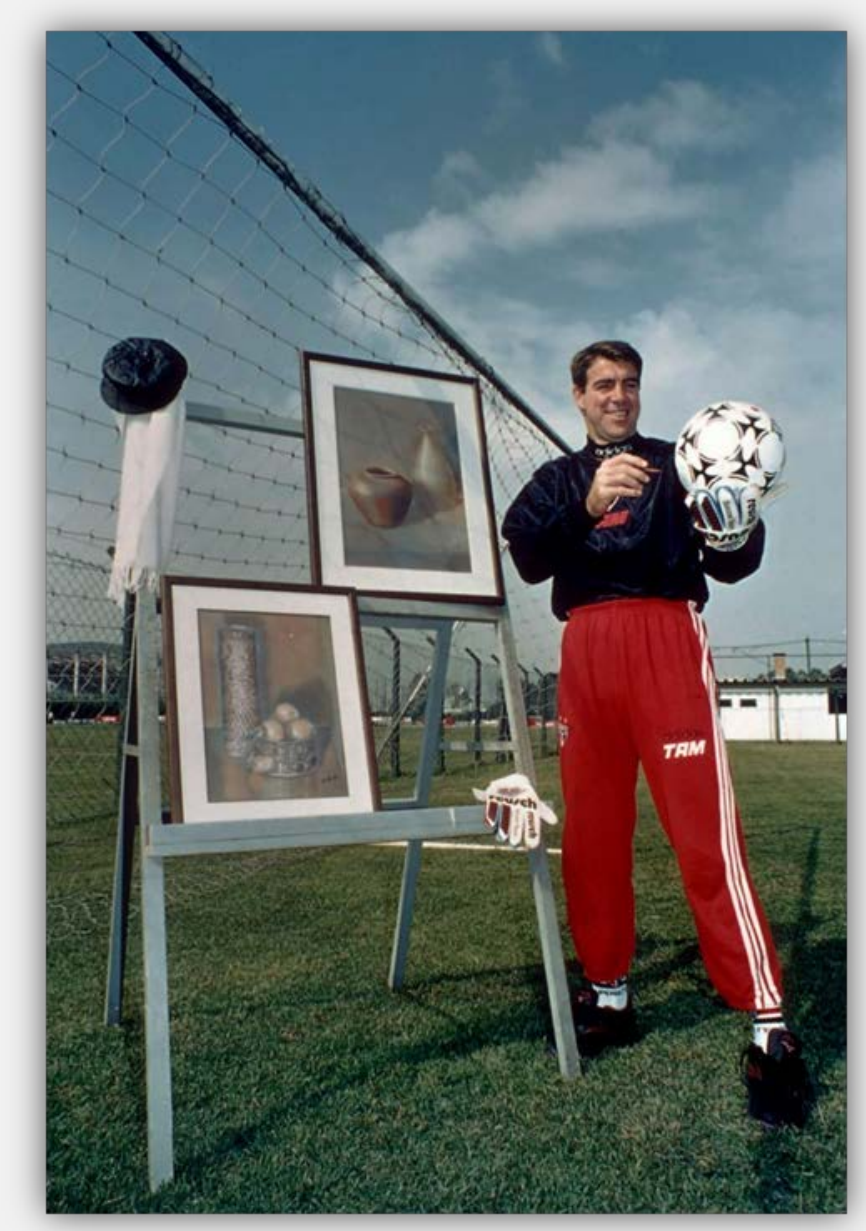

Zetti com quadros pintados: treino do São Paulo, 1996 


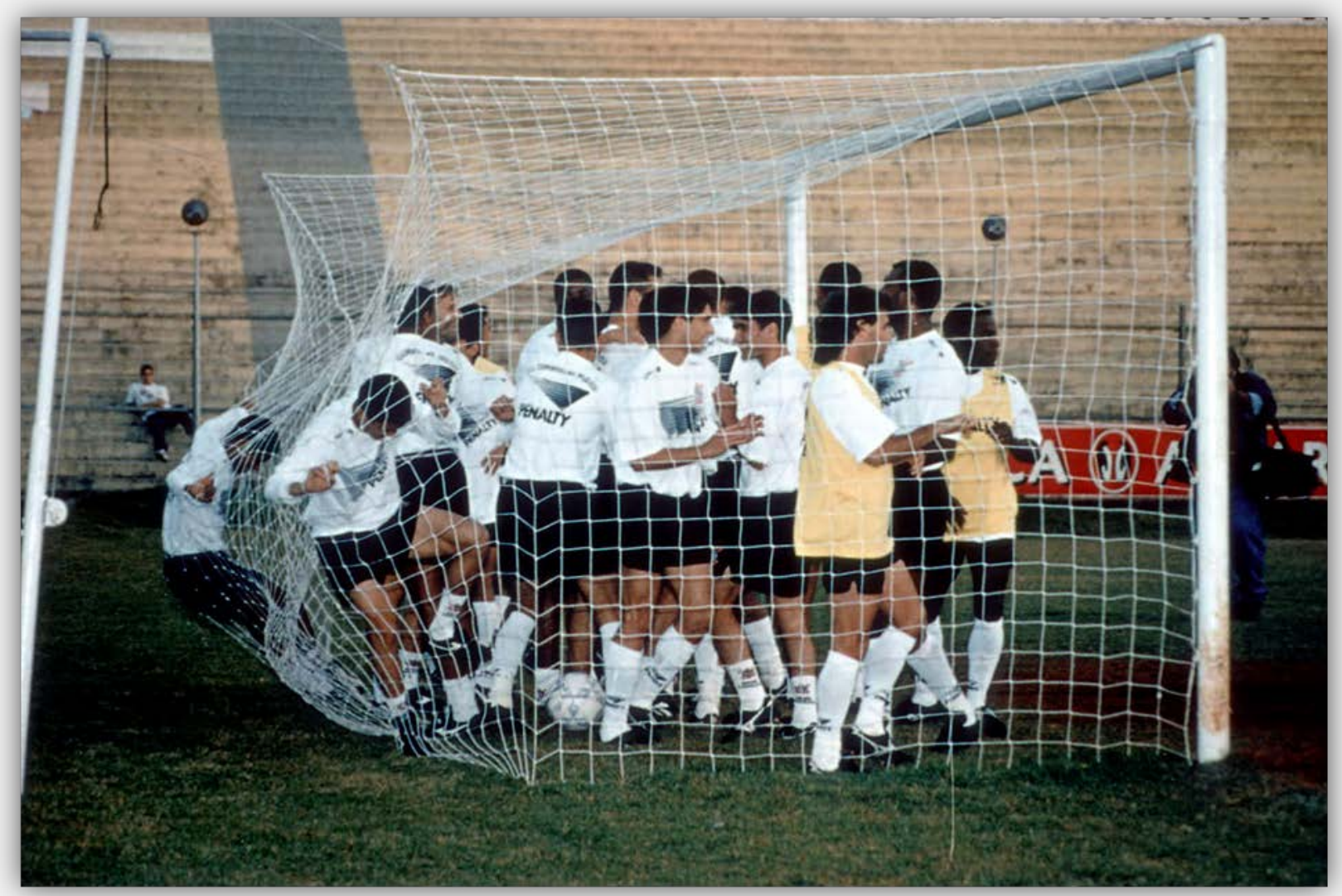

Treino do Corinthians (1), 1996 


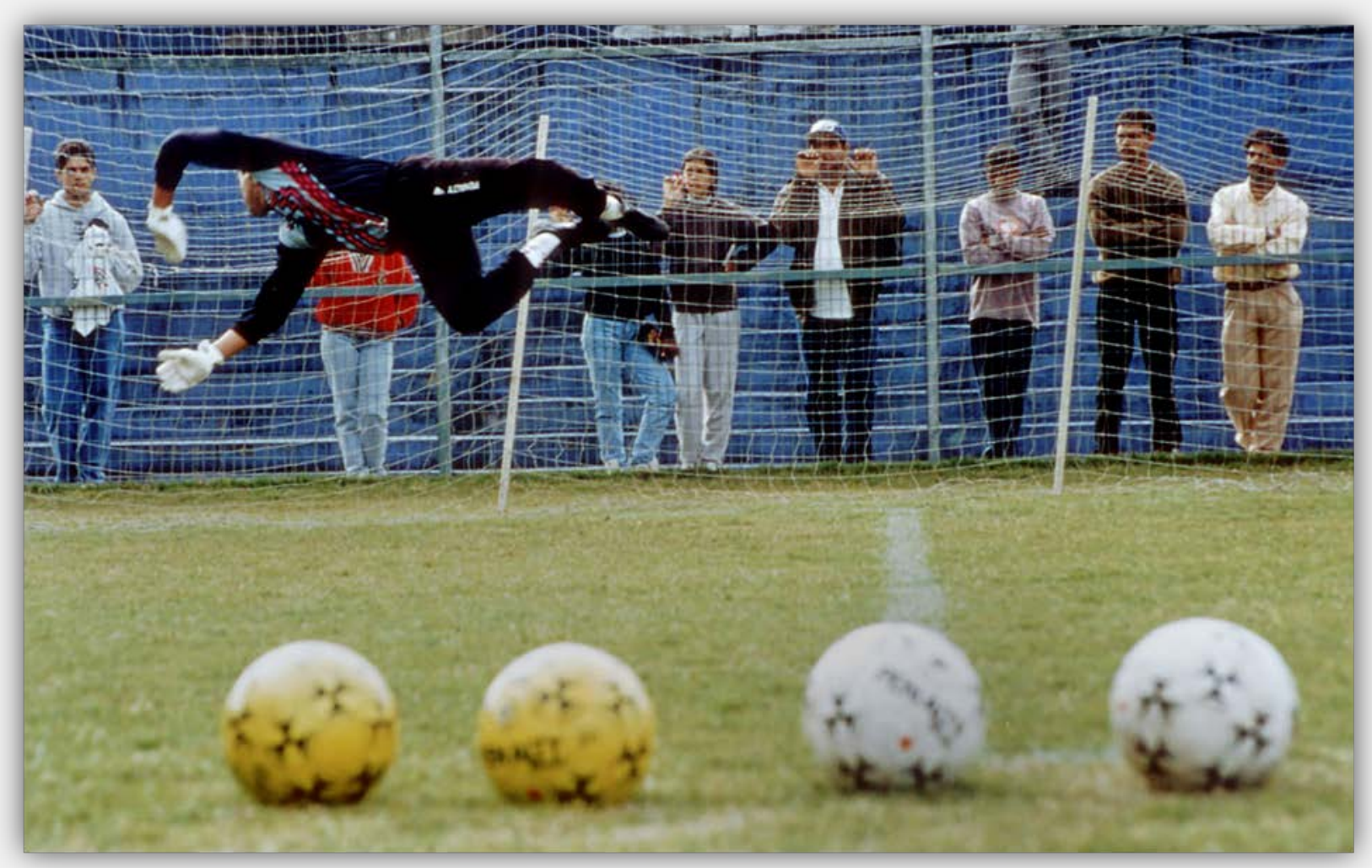

Treino do Corinthians (2), 1996 


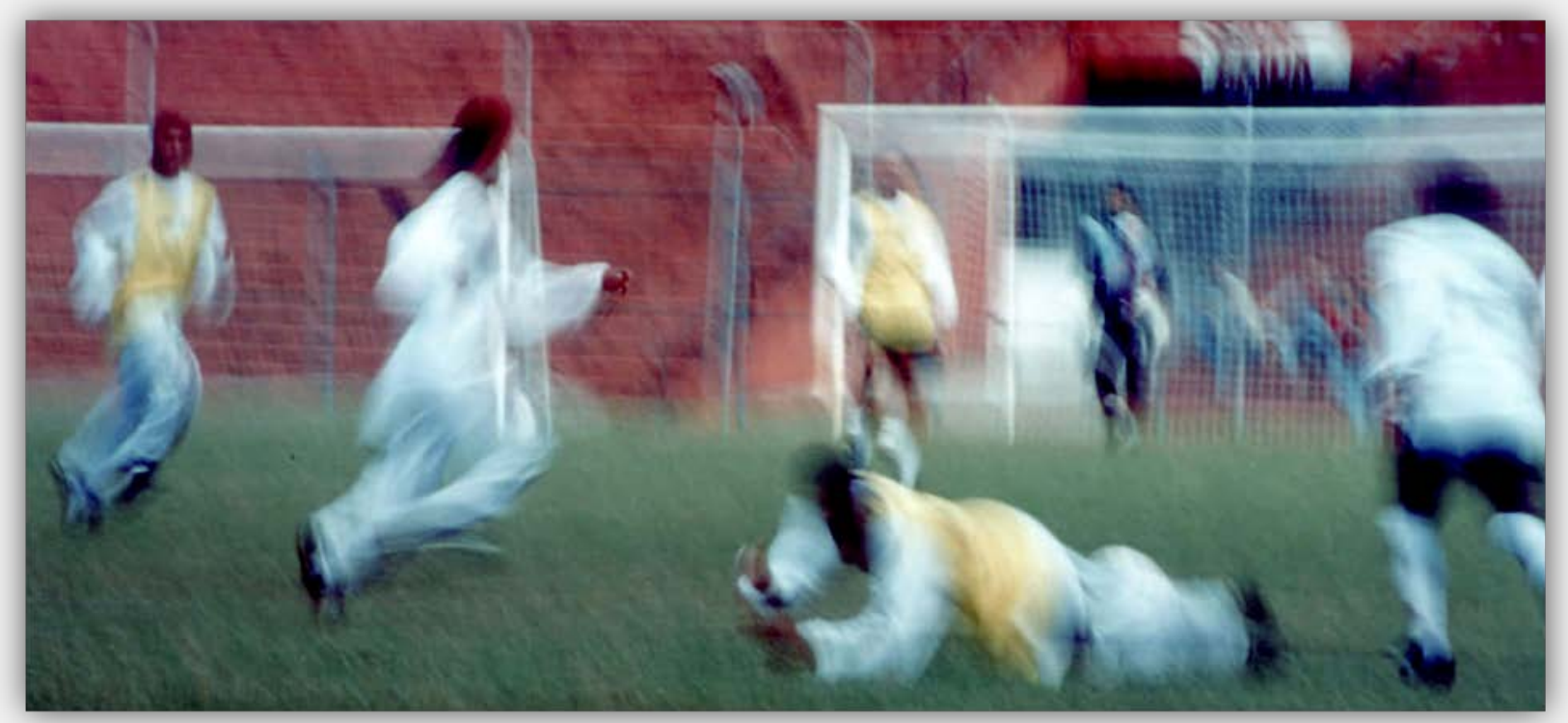

Treino do Corinthians (3), 1996 


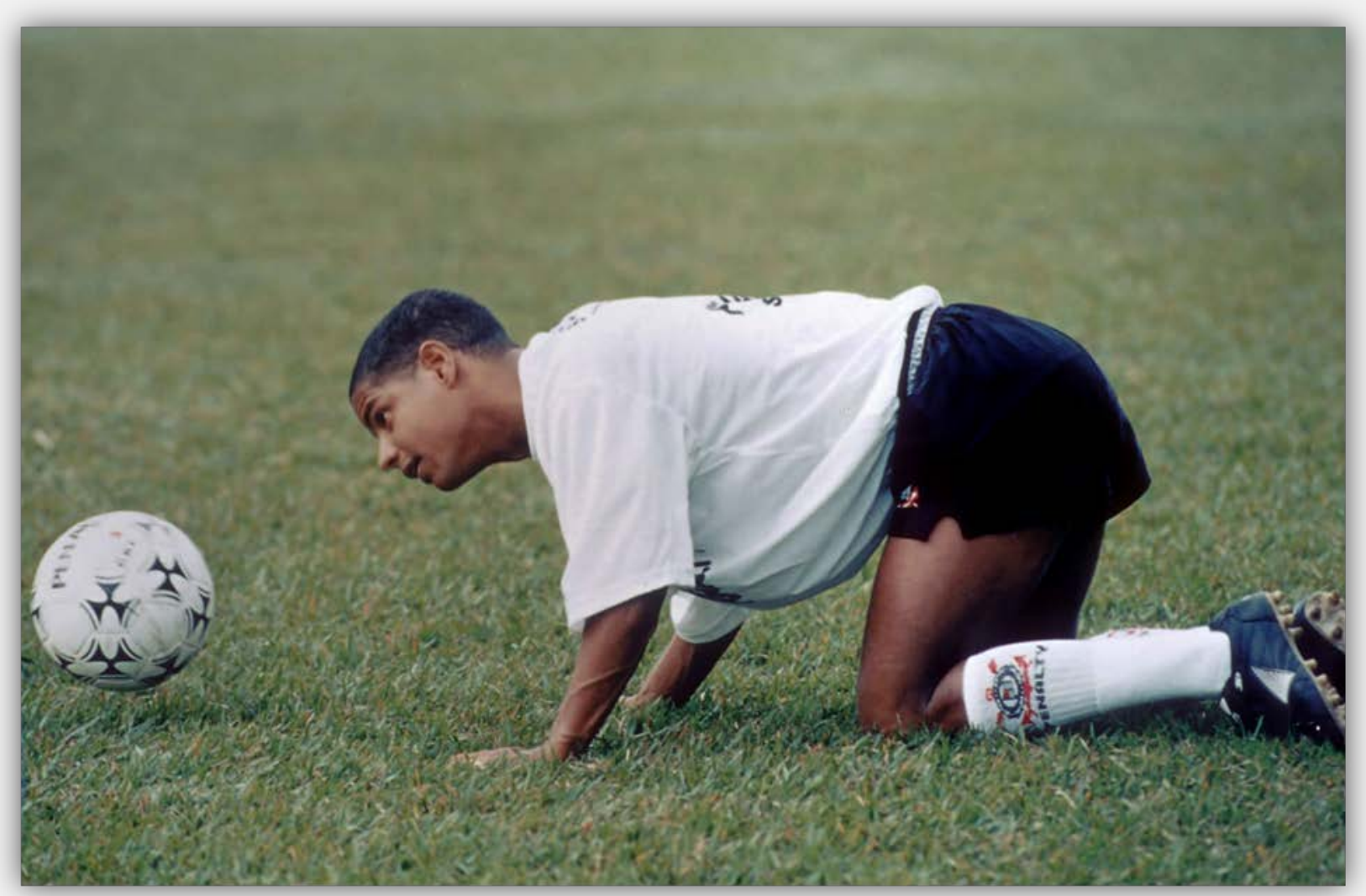

Marcelinho Carioca: treino do Corinthians, 1996 


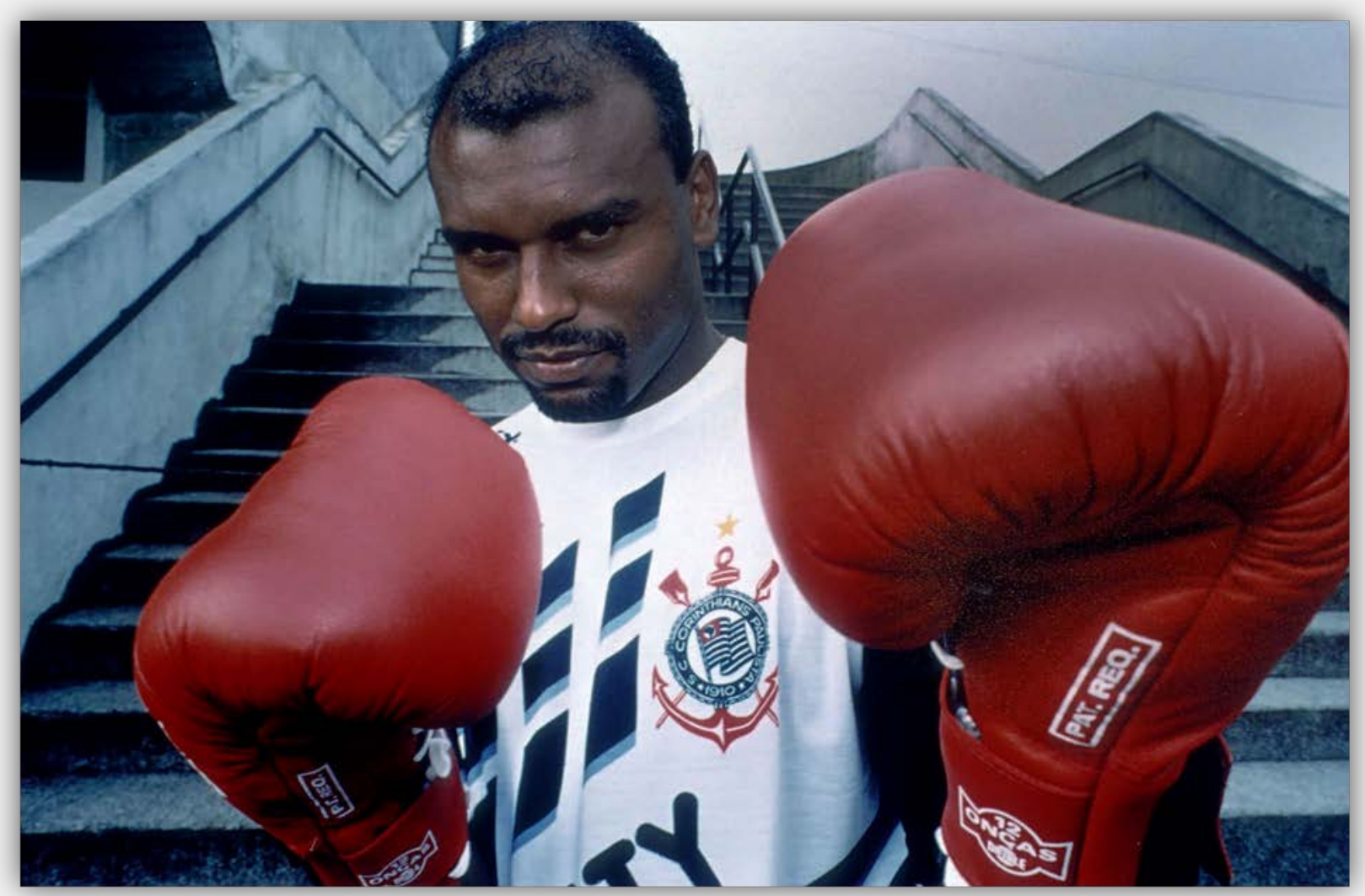

Célio Silva: treino do Corinthians, 1996 


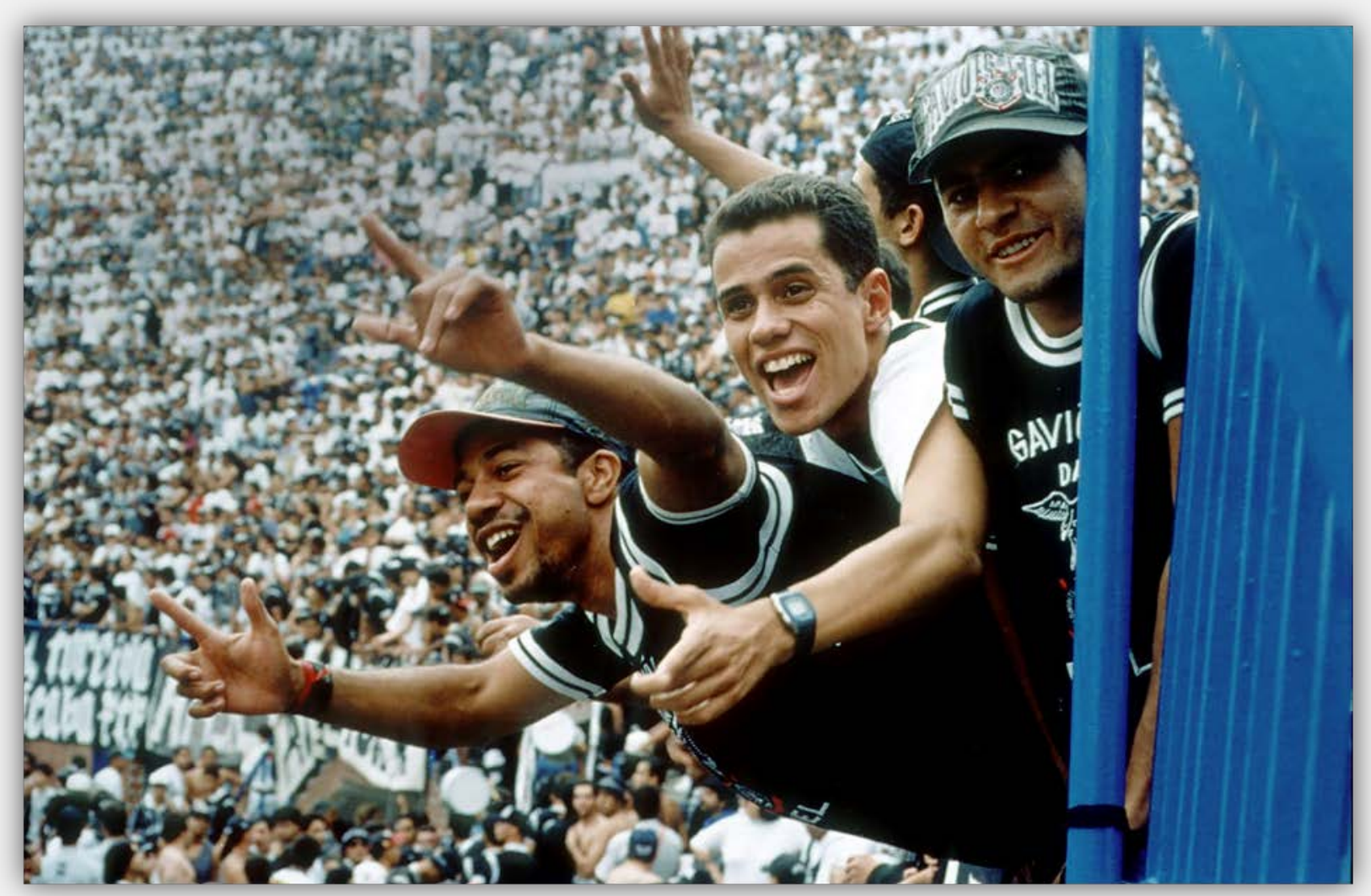

Gaviões da Fiel: Pacaembu, 1995 


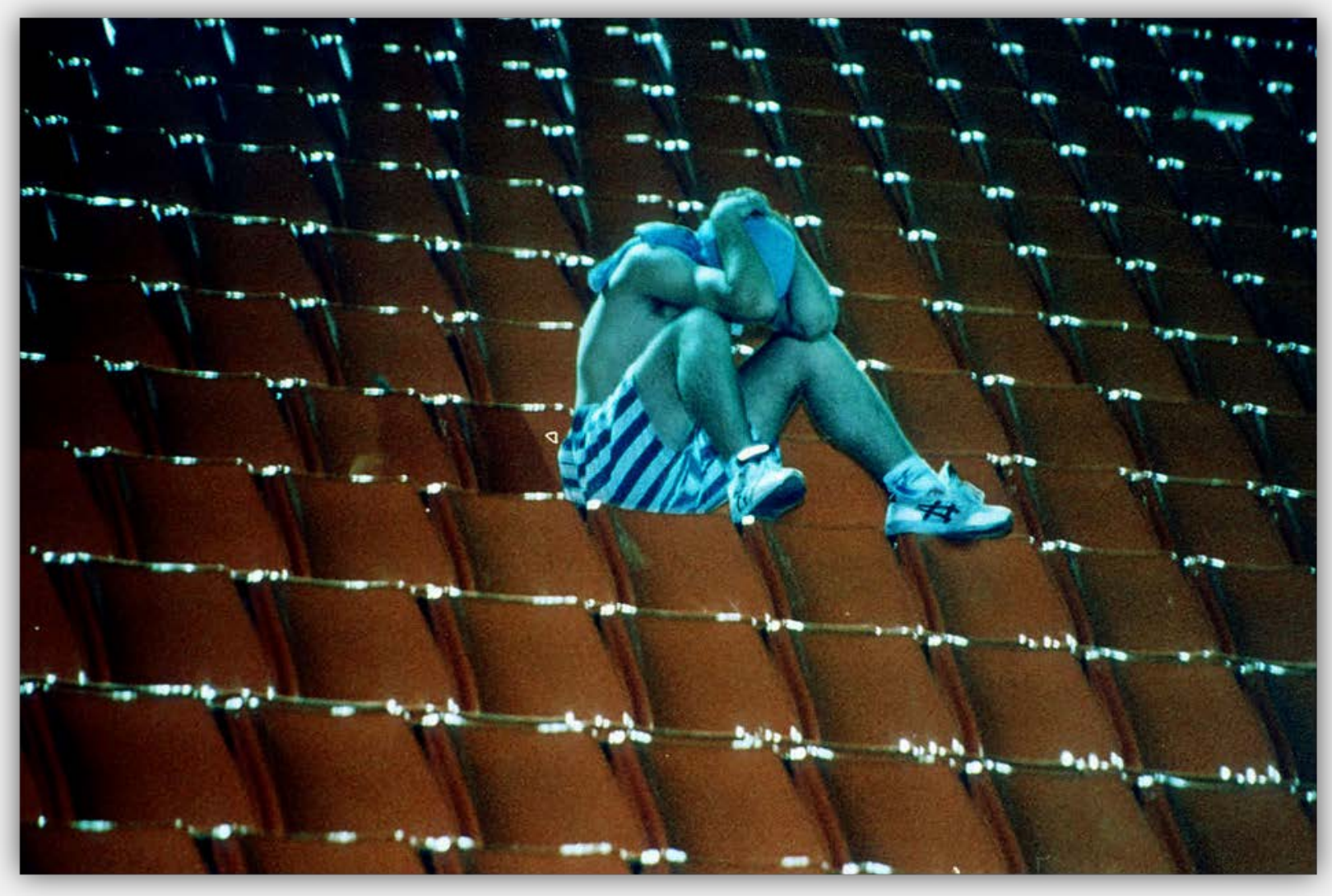

Torcedor: Pacaembu, 1995 


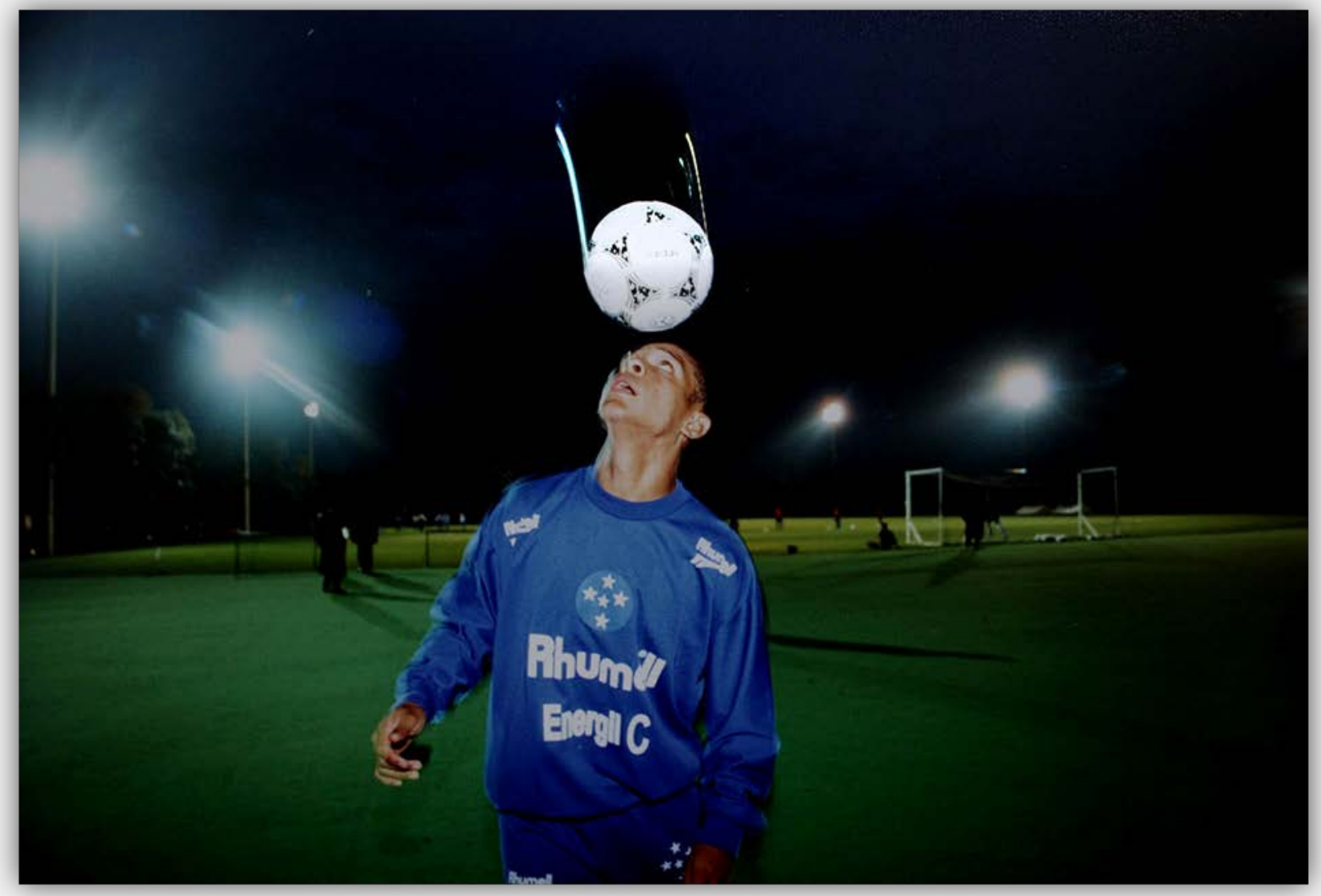

Geovanni Deiberson: treino do Cruzeiro no J apão, 1997 


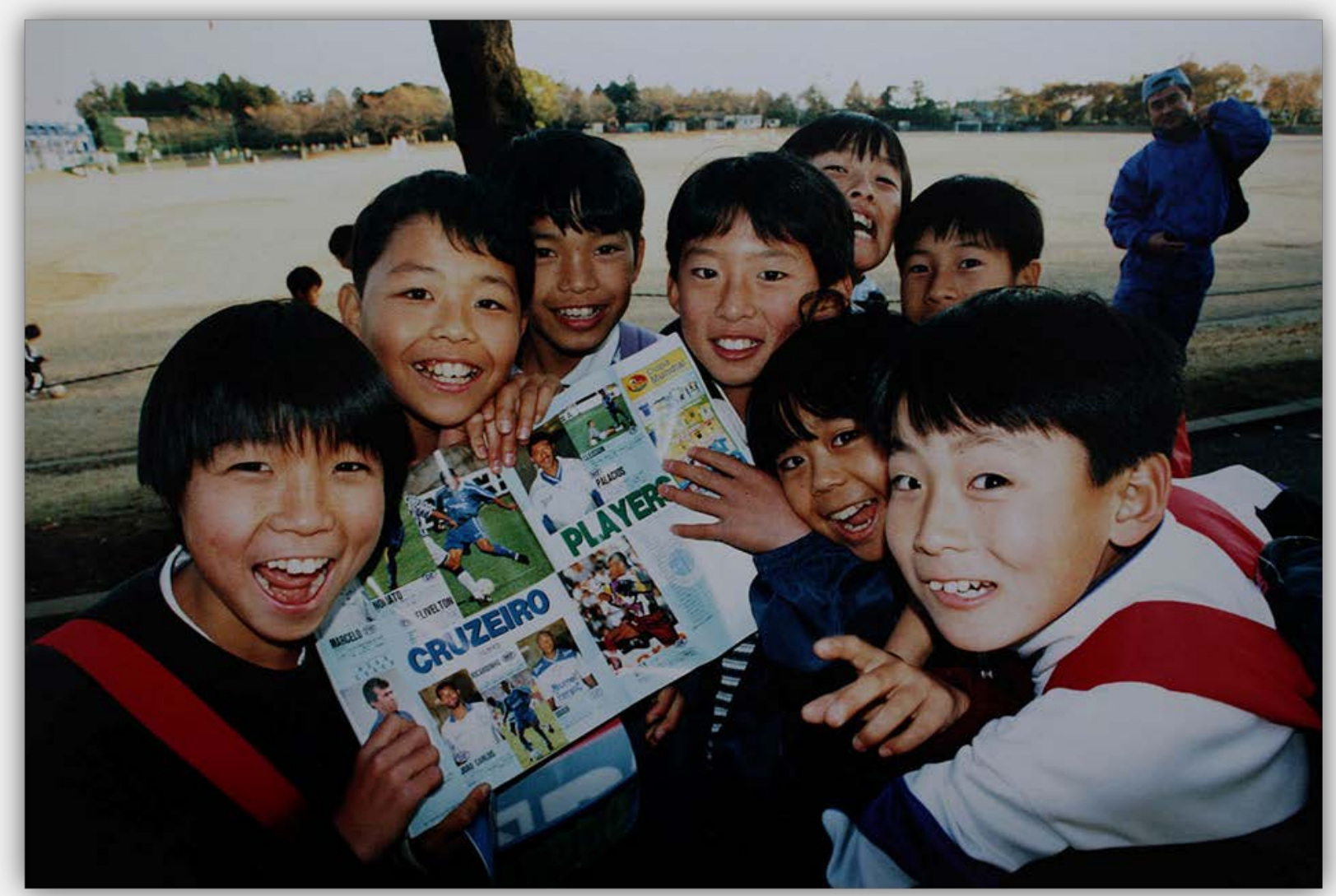

Torcedores mirins do Cruzeiro no J apão, 1997 


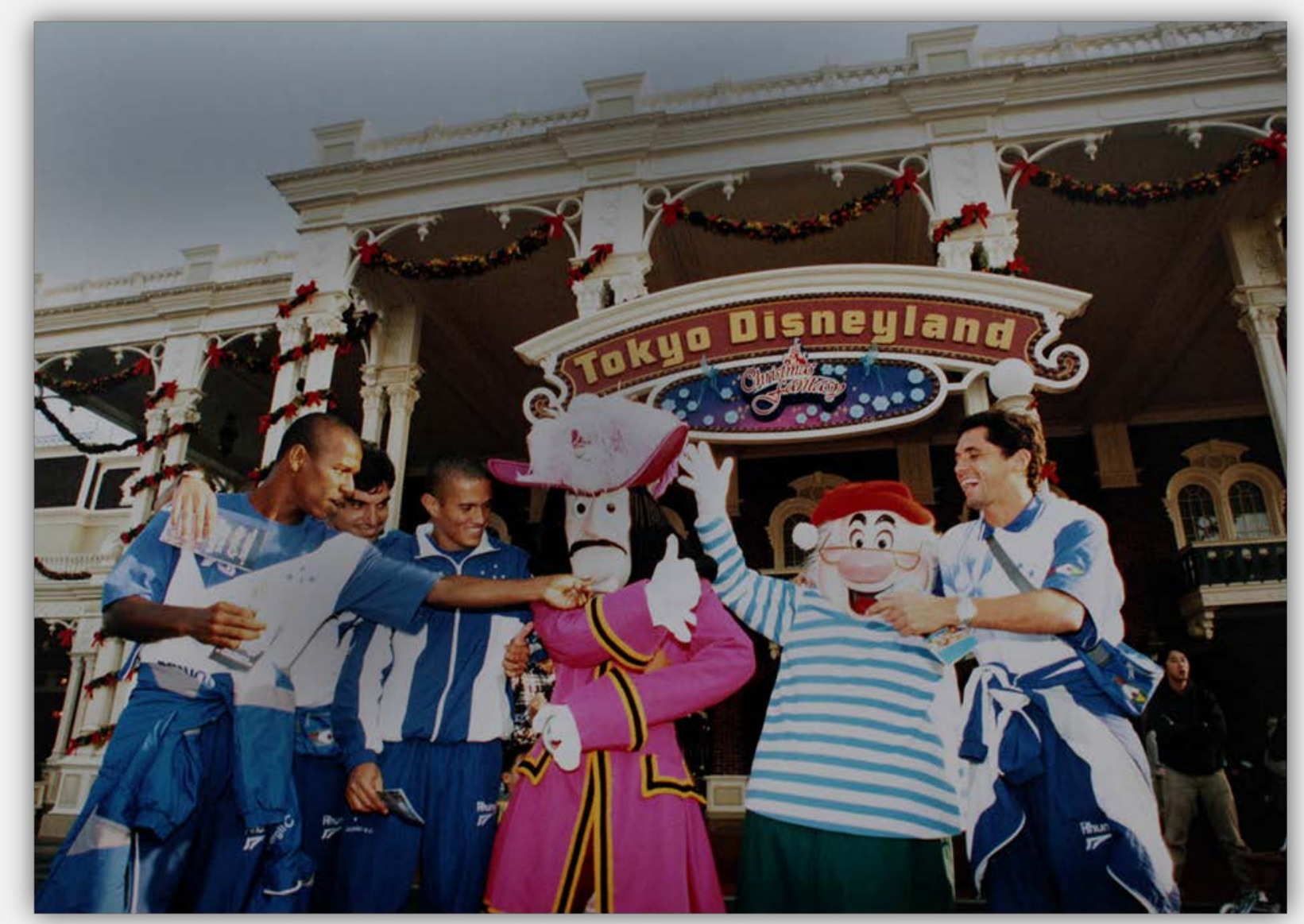

J ogadores do Cruzeiro visitam Tokyo Disneyland, 1997 


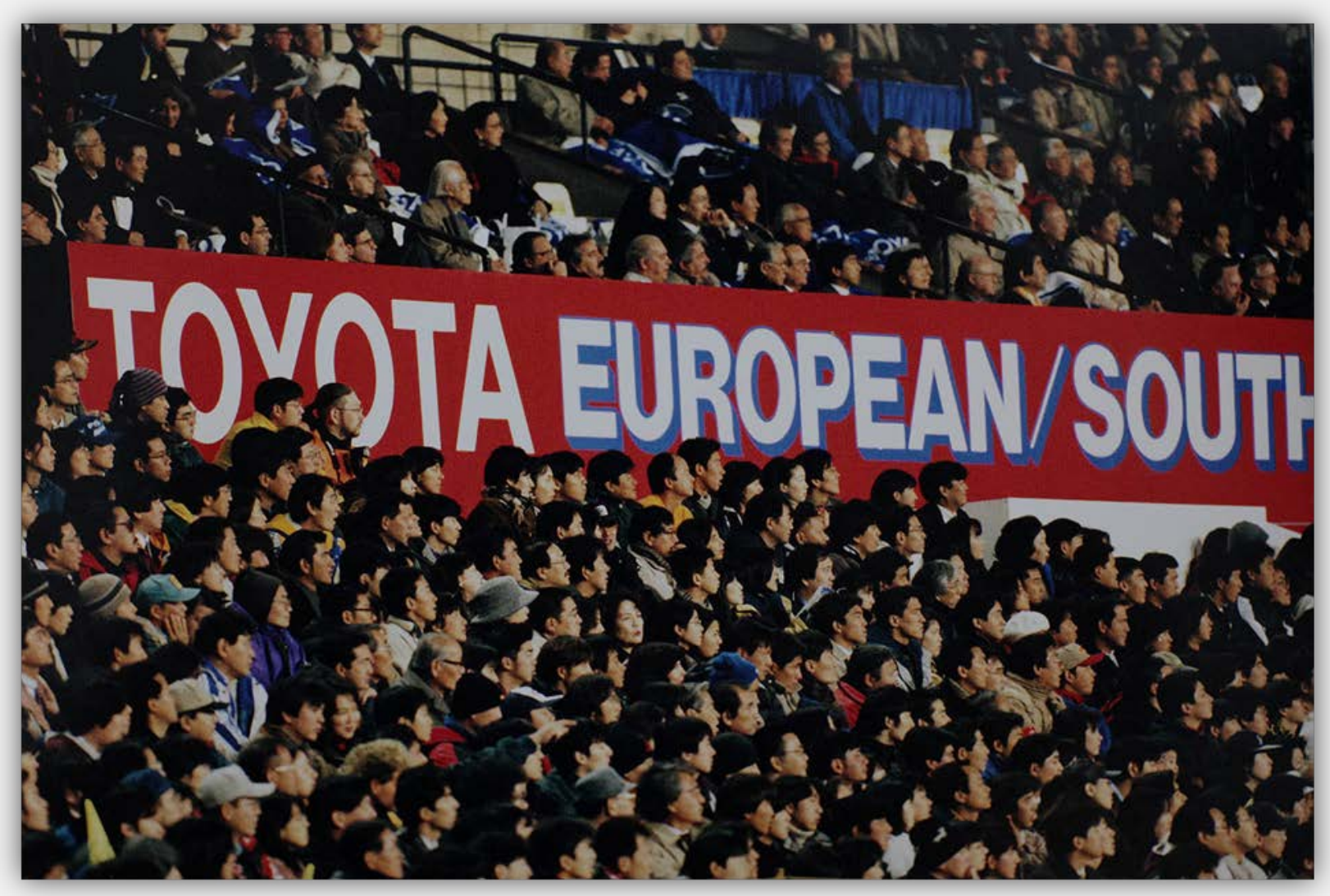

Torcedores do Cruzeiro na final contra o Borussia no J apão, 1997 


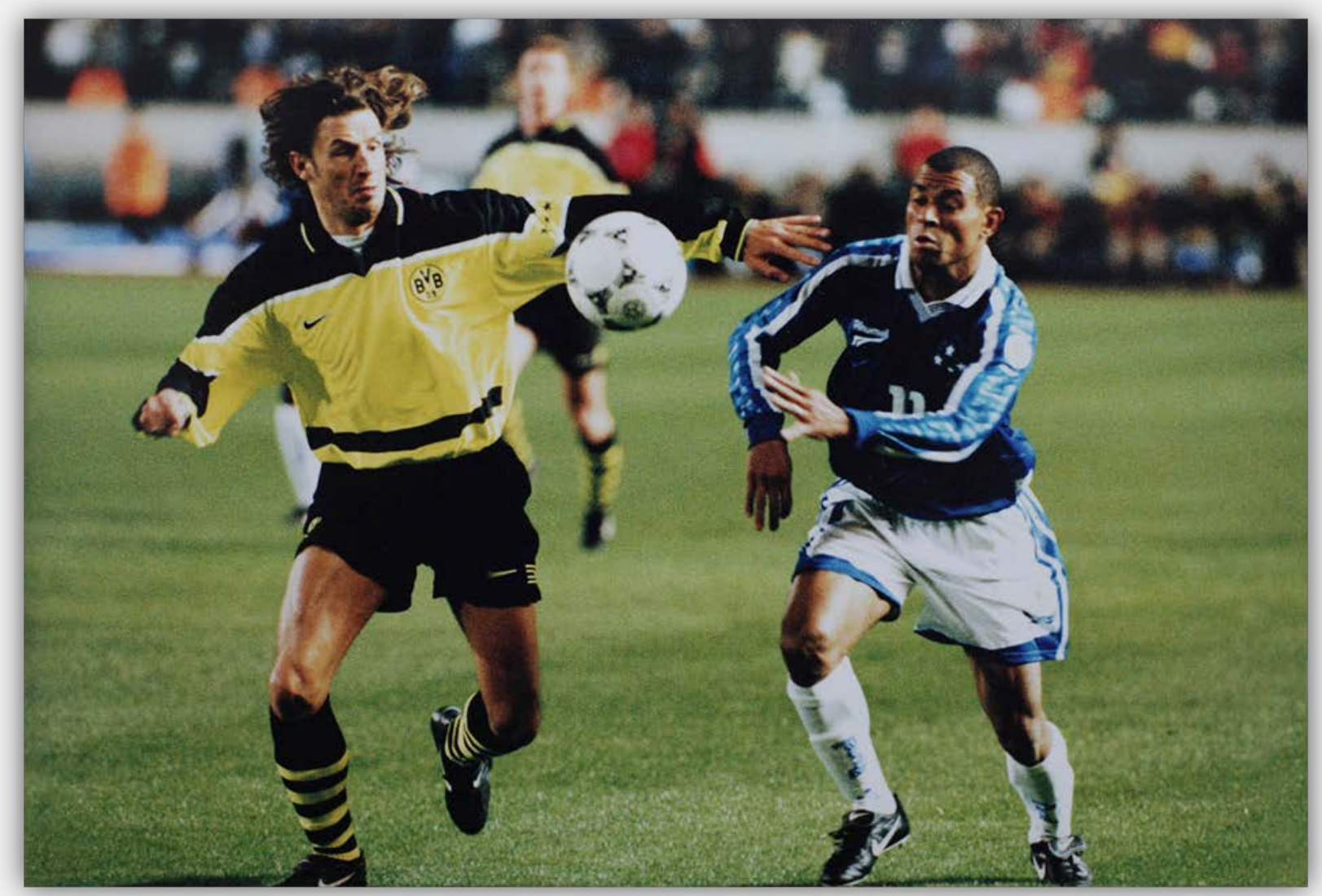




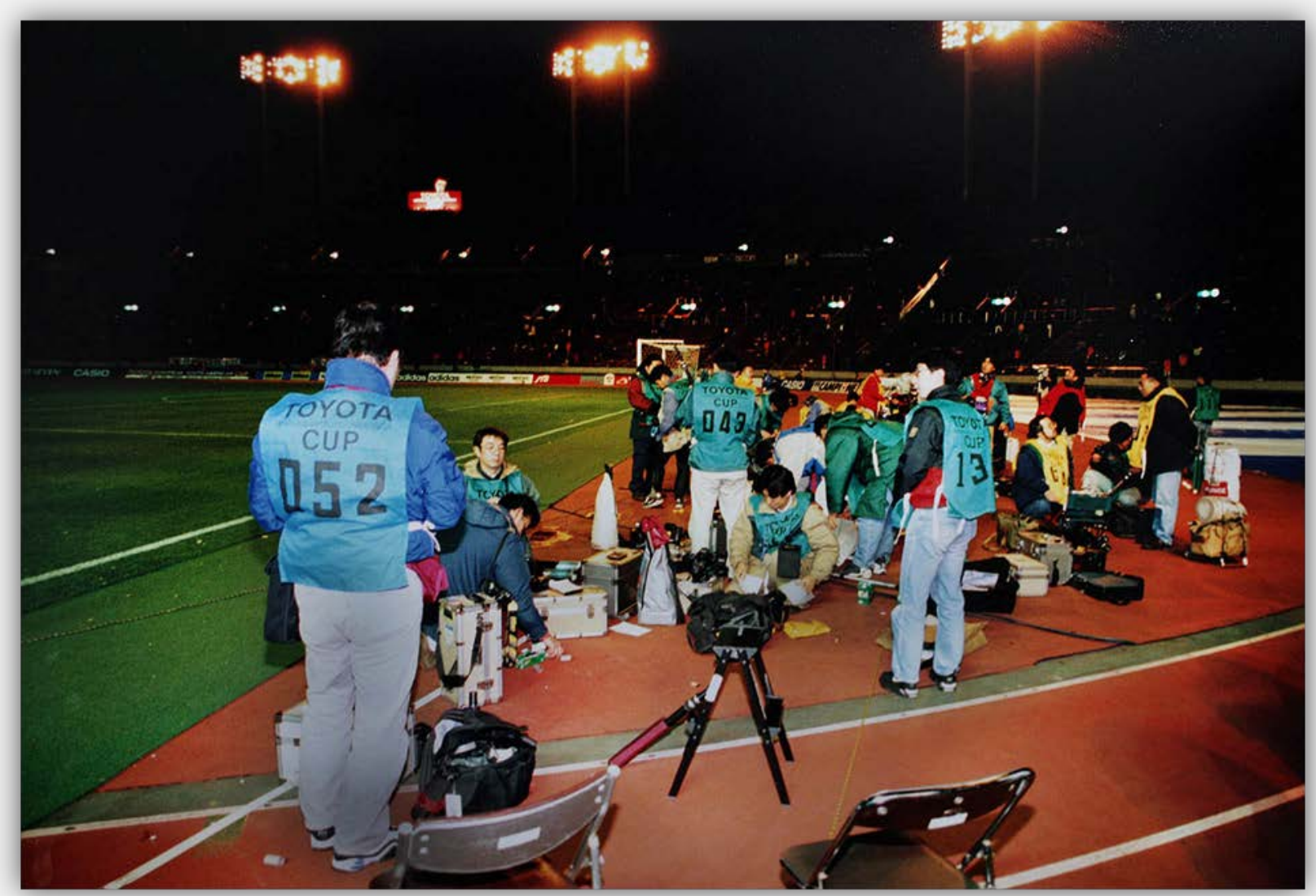


Fotógrafos na final da Copa Toyota no J apão, 1997

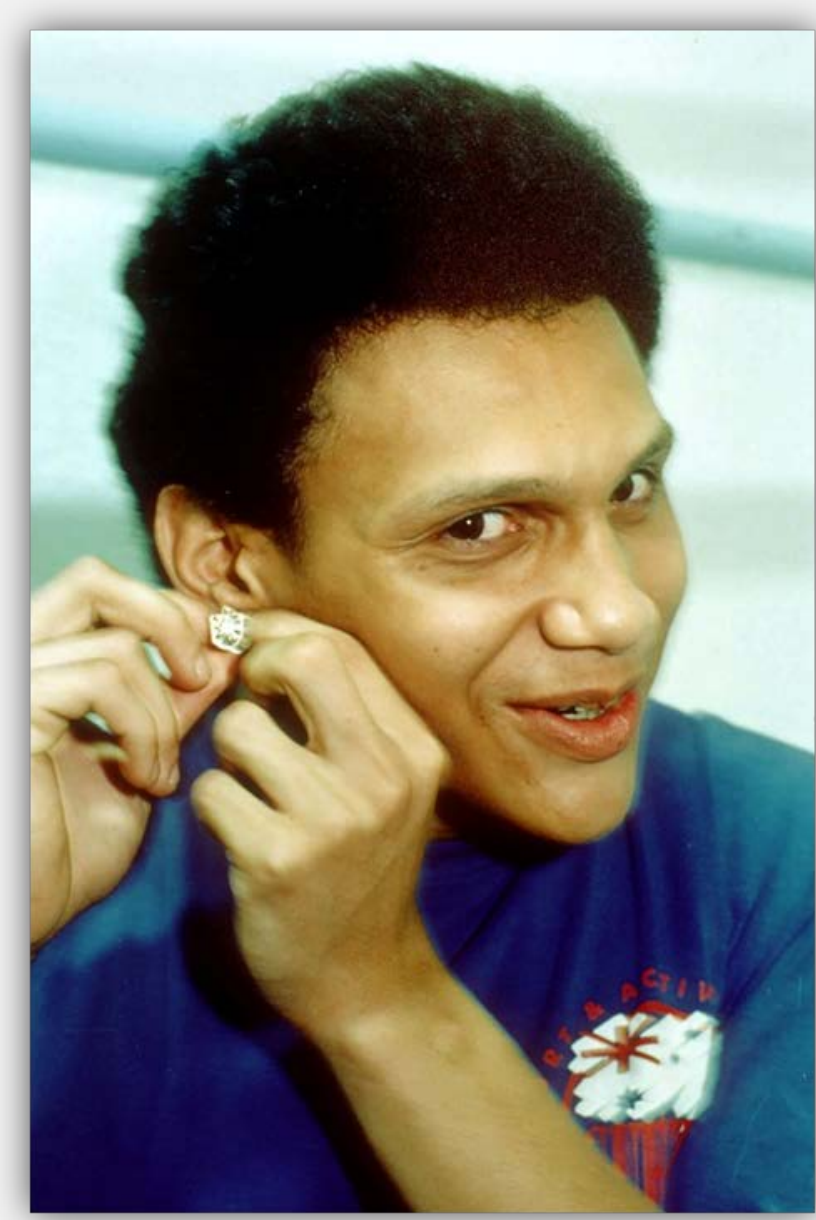




\section{Edinanci Silva: judoca, 1995}

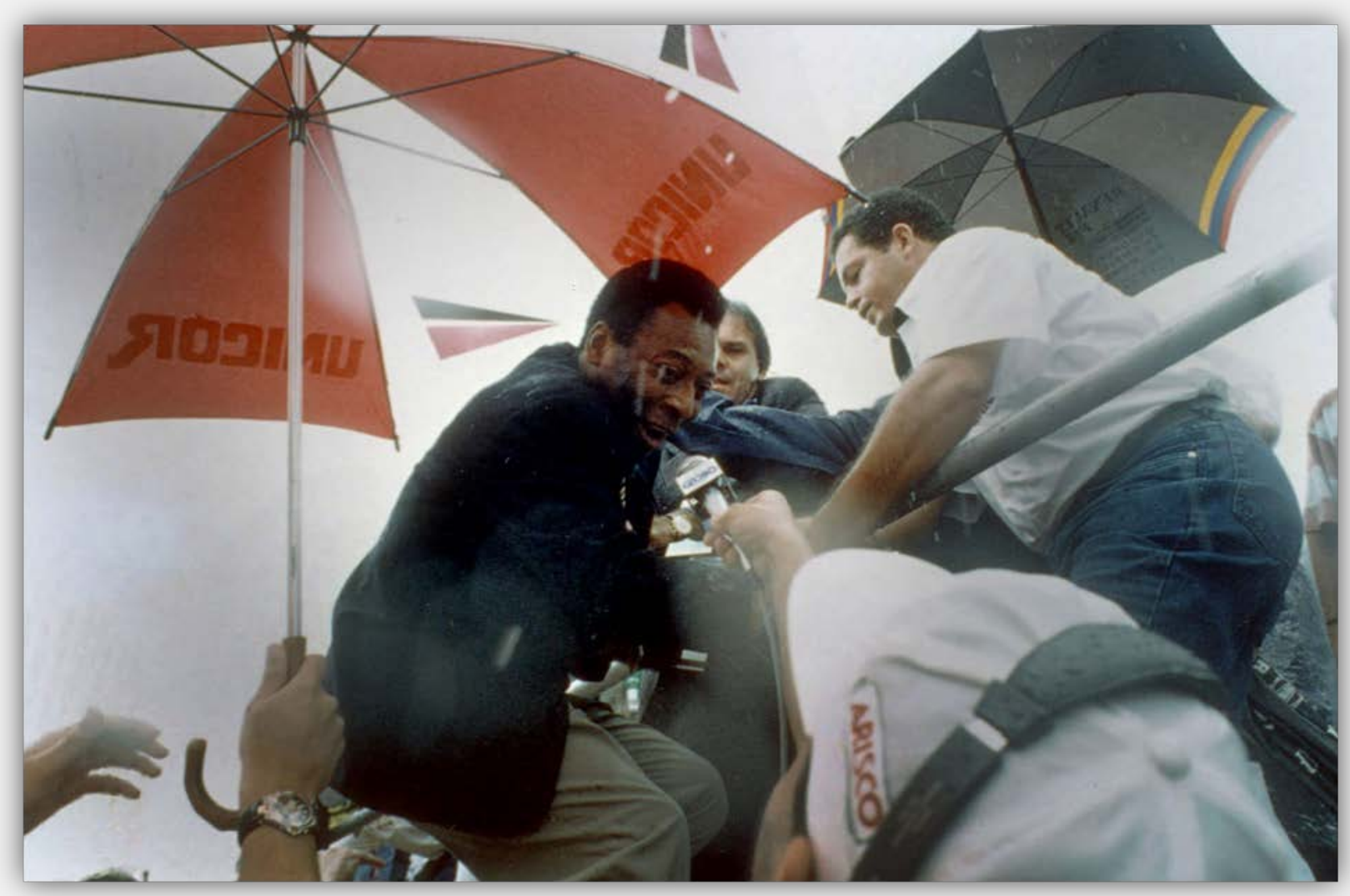


Pelé: Interlagos, 1996

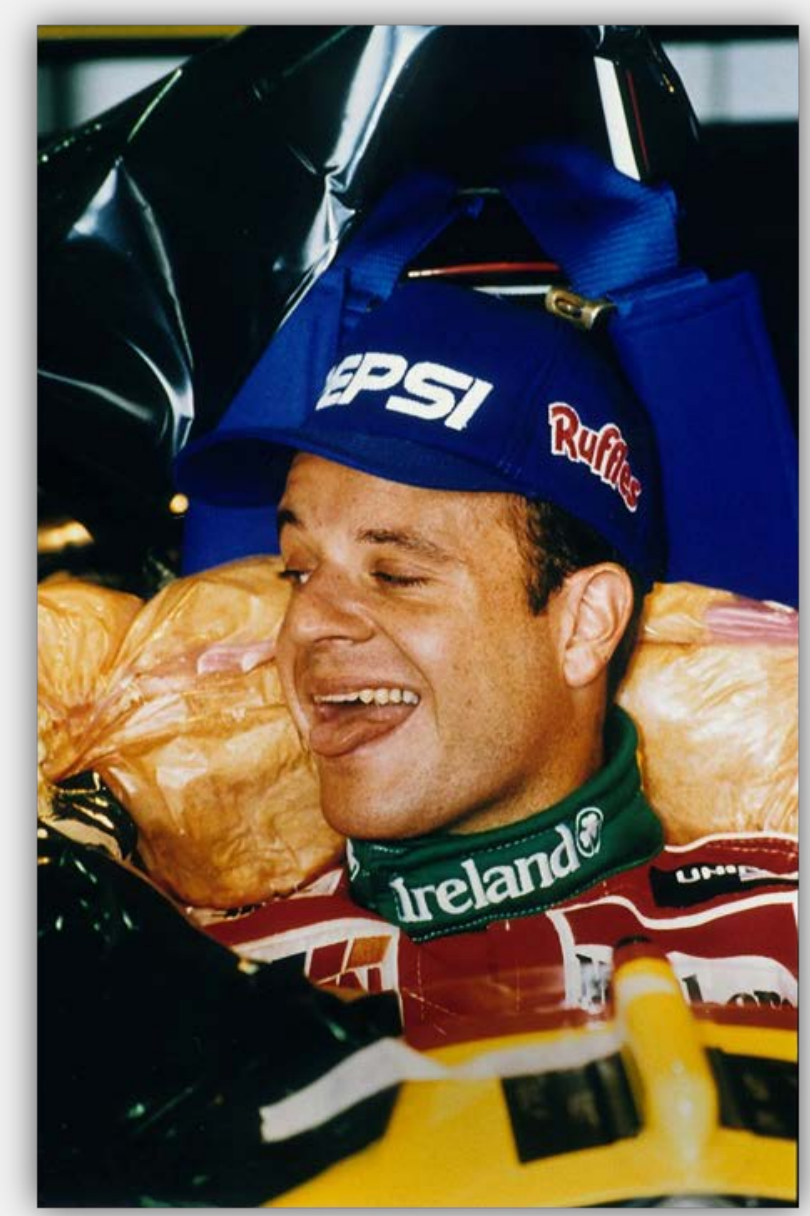


Rubinho Barrichello: Interlagos, 1995

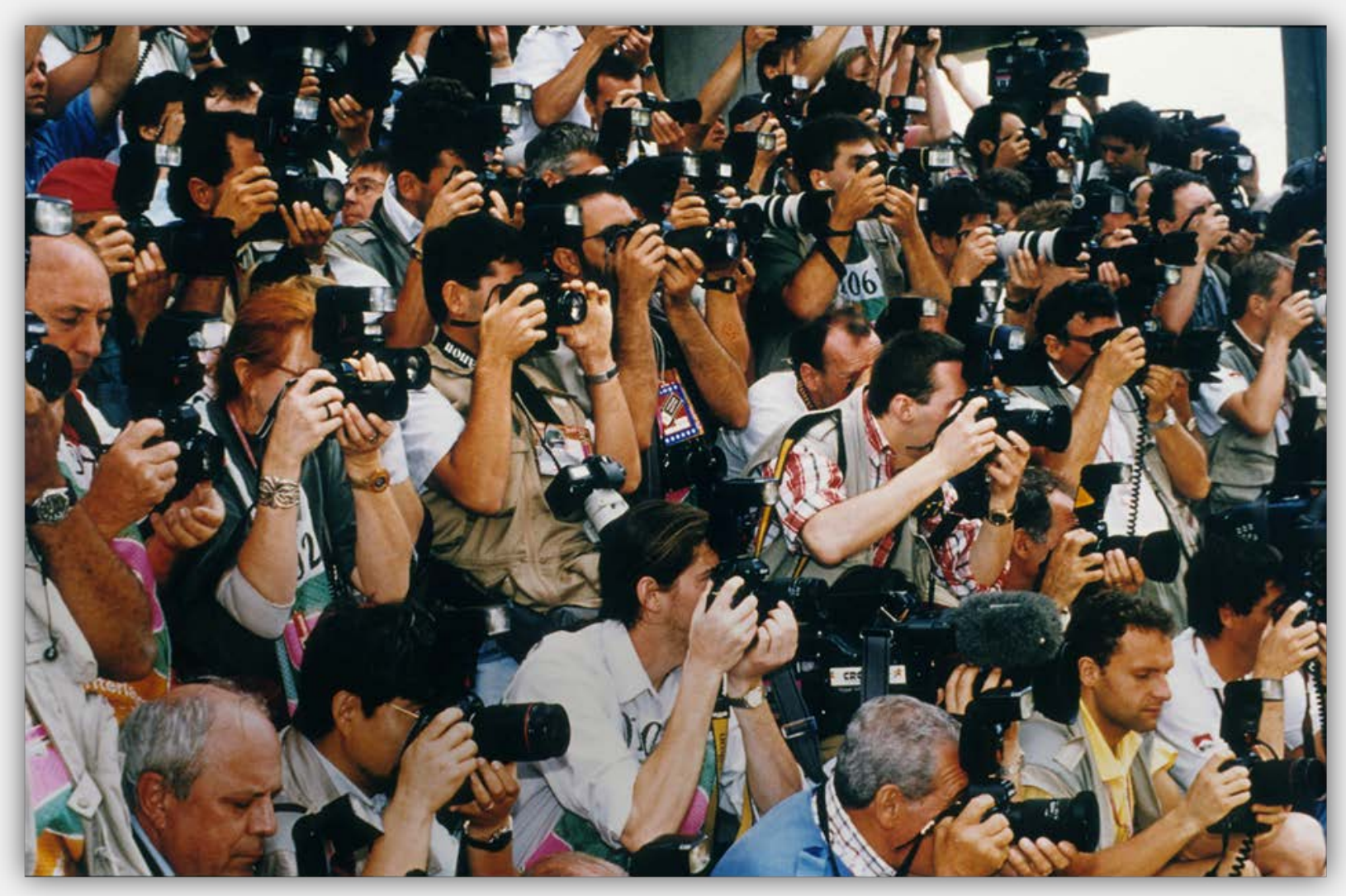


Fotógrafos: Interlagos, 1995

Capa da revista FuLiA / UFMG, v. 5, n. 1, 2020.

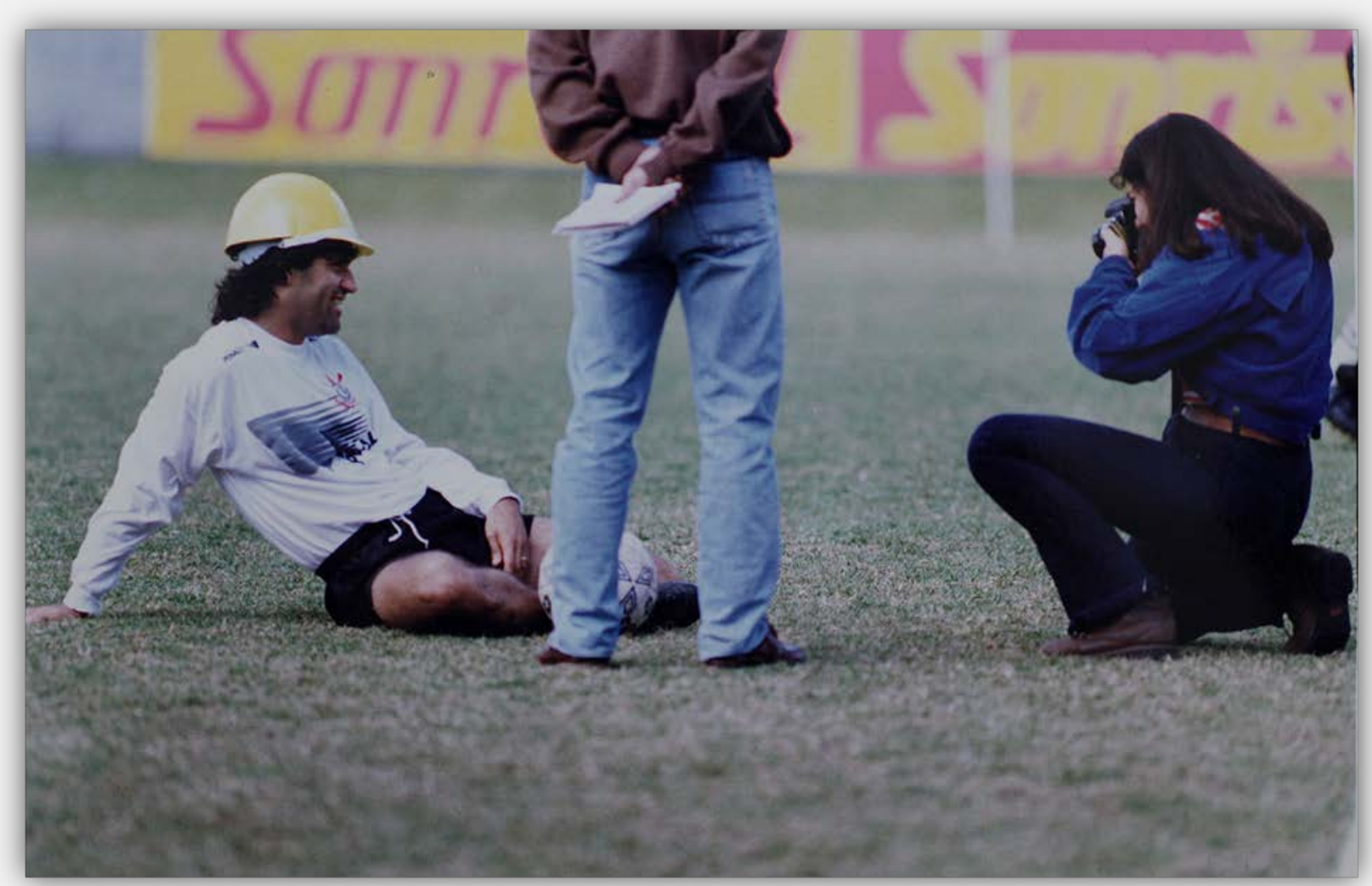




\section{Kátia Lombardi fotografando jogador do Corinthians}

(Arquivo pessoal). 